\title{
Nutritional Survey of Mosambi Orchards at Jamsar and Lunkaransar Soil Series of Bikaner District of Arid Rajasthan
}

\author{
Dinesh Kumar $^{1 *}$, B. L. Kumawat ${ }^{2}$, B. D. Sharma ${ }^{3}$ and Ramandeep Kaur ${ }^{1}$ \\ ${ }^{1}$ Department of Soil Science and Agricultural Chemistry, College of Agriculture, Jaipur \\ National University, Jaipur - 302017 Rajasthan, India \\ ${ }^{2}$ Department of Soil Science and Agricultural Chemistry, Agricultural Research Station, S.K. \\ Rajasthan Agricultural University, Bikaner - 334006 (Rajasthan), India \\ ${ }^{3}$ ICAR-Central Institute of Arid Horticulture, Bikaner - 334006 (Rajasthan), India \\ *Corresponding author
}

\section{A B S T R A C T}

\begin{tabular}{|l|}
\hline K e y w o r d s \\
$\begin{array}{l}\text { Correlation, Fruit } \\
\text { characters, Juice } \\
\text { nutrient, Mosambi, } \\
\text { Micronutrients, Soil } \\
\text { survey }\end{array}$ \\
\hline Article Info \\
\hline $\begin{array}{l}\text { Accepted: } \\
\text { 07 November } 2019 \\
\text { Available Online: } \\
\text { 10 December } 2019\end{array}$ \\
\hline
\end{tabular}

\section{Introduction}

Fruit cultivation in India is spread over an area of $6.37 \mathrm{~m}$ ha and production is $92.91 \mathrm{MT}$ (NHB 2016-17). India has large arid zones covering an area of $317090 \mathrm{sq} \mathrm{km}$ mainly located in the North-West parts of the country
The present study was aimed at evaluating the fertility status of mosambi orchards at Jamsar and Lunkaransar series of Bikaner district in irrigated area of arid Rajasthan. All mosambi orchards soils were found alkaline to saline in nature, $\mathrm{EC}_{2} \mathrm{Of}$ all the orchard soil samples was normal. The $\mathrm{CaCO}_{3}$ content in soils showed increasing trend with depth, low in organic carbon and available $\mathrm{N}$, Low to medium in available $\mathrm{P}_{2} \mathrm{O}_{5}$, Medium to high in available $\mathrm{K}_{2} \mathrm{O}$ content, Majority of samples were found low in available $\mathrm{Fe}$ and $\mathrm{Zn}$ content, low to sufficient in available $\mathrm{Cu}$ and high in available $\mathrm{Mn}$ content. Leaf $\mathrm{N}$ content were found low in mosambi orchards, majority of leaf samples found optimum in leaf P, $\mathrm{Fe}$, and Mn content, whereas leaf $\mathrm{K}$ content were found low in mosambi orchards. The leaf $\mathrm{Cu}$ and $\mathrm{Zn}$ content were found low to optimum range in mosambi orchards soils. The mosambi juice $\mathrm{N}, \mathrm{P}, \mathrm{K}, \mathrm{Fe}, \mathrm{Mn}, \mathrm{Cu}$ and $\mathrm{Zn}$ contain were found low to optimum range in mosambi orchards at Jamsar and Lunkaransar series of Bikaner district. The fruit yield and quality parameters were significantly influenced by the status of nutrients in mosambi leaves. The studied area signifying the prominent role of leaf nutrition in determining the yield potential and fruit quality at a given soil fertility level. Based on the findings of the present investigation application of $\mathrm{N}, \mathrm{P}, \mathrm{Fe}, \mathrm{Cu}$ and $\mathrm{Zn}$ fertilizer nutrients need to be addressed in mosambi orchards soils in the studied area for optimizing higher productivity. 
Rajasthan is only 0.19 thousand hectare and production is 2.35 thousand MT indicated that still there is a scope to increase the area and productivity level of mosambi fruits cultivation in the state. Mosambi cultivation is becoming very popular among farmers of Bikaner district in Indira Gandhi canal command area of Jamsar and Lunkaransar series. Bikaner district has approximately 2.81 lac hectare canal irrigated area which has great potential for expanding area under mosambi cultivation. Very little work has been done on soil environment and nutrient concentration and quality of mosambi growing particularly in Bikaner districts of arid Rajasthan. Hence, the research programme on mosambi was taken up to find out the probable reasons for the decline of mosambi orchards with respect to soil factors and leaf nutrient concentration that influencing yield and quality of fruits.

\section{Materials and Methods}

\section{Study area}

The present study was carried out at Jamsar and Lunkaransar soil series of Bikaner district in canal irrigated areas of western Rajasthan covers an area of 117300 and 104240 ha, respectively. Physiographic position of western plains marusthali has Lunkaransar and Jamsar soil series (Bikaner district).

According agro climatic zone Bikaner district comes under Ic i.e. Hyper arid partially irrigated western plain.

\section{Characteristics of soil series and climate}

Jamser series is a member of coarse loamy, mixed (cal.) hyperthermic family of Calcic Haplogypsids. Typically Jamsar soils are very deep, well drained and have dark yellowish brown, sandy, mildly alkaline overburden on dark yellowish brown, sandy loam, moderately alkaline Ahorizon. Lunkaransar series is a member of coarse loamy, mixed (cal.) hyperthermic family of Typic Haplocambids. Typically Lunkaransar soils are very deep, well drained and have dark yellowish brown, sandy loam, moderately alkaline A and B horizon (Shyampura et al., 2002). The mean annual rainfall ranges between 200 and $300 \mathrm{~mm}$. The rainfall received is its peak during the month of August and second fortnight of September.

\section{Soil sampling and analysis}

Soil samples from surface $(0-30 \mathrm{~cm}$ depth) and sub-surface $(30-60 \mathrm{~cm}$ depth) from each orchards (10Mosambi orchards) of selected soil series in Bikaner district were collected with the help of a wooden khurpi. Samples were completely air-dried and passed through $2 \mathrm{~mm}$ sieve and stored in properly labeled plastic bags for analysis. The $\mathrm{pH}$ and electrical conductivity of the soil samples were measures in 1: 2 soil water suspension described by Richards (1954). The content of organic carbon in the soil samples was determined using the procedures described by Piper (1950) and calcium carbonate was estimated by rapid titration method described by Hutchinson and McLennan (1914).

Available $\mathrm{N}$ was determined using alkaline permanganate method described by Subbiah and Asija (1956), Available P was determined extract by $0.5 \mathrm{M} \mathrm{NaHCO}$ at $\mathrm{pH} 8.5$ and 3 development of color for colorimetric measurement by Olsen et al., (1956), Available $\mathrm{K}$ was determined using flame photometer described by Metson (1956), Available $\mathrm{Zn}, \mathrm{Fe}, \mathrm{Cu}$ and $\mathrm{Mn}$ contents in soil samples were determined using AAS described by Lindsay and Norvell (1978).

\section{Leaf sampling and analysis}

The methodology for leaf sampling suggested by Singh et al., (1989) for mosambi was 
followed. Composite leaf samples from four trees in each orchard of the soil series was collected from third pair of leaf apex in the early morning or late evening hours during the month of March-April, 2015 from 10-15 years age old plants with a sample size of 60 leaves from all the four directions for nutritional diagnosis. Samples collected were kept in paper bag and quickly brought to the laboratory. These samples were washed thoroughly by using 0.2 per cent detergent solution to remove waxy coating on the leaf surface. Thereafter washed with $\mathrm{N} / 10 \mathrm{HCl}$ solution to remove heavy metals like Fe, Mn, $\mathrm{Zn}$, etc., followed by distilled water to remove acid and detergent residue and finally in double distilled water. After cleaning samples were put in a new paper bag and placed in hot air oven at $70 \mathrm{C}$ for 24 hours. After drying sample were ground and 0 stored in clearly labeled polythene bags for further analysis.

Plant sample was digested by using $\mathrm{H} \mathrm{SO}$ and $\mathrm{H} \mathrm{O}$ carried 2422 out for nitrogen and determined $\mathrm{N}$ content by colorimetric method using spectrophotometer described by Snell and Snell (1949), Plant P content determined by Vanadomolybdophosphricacid yellow colour method described by Jackson (1973), plant $\mathrm{K}$ content $\mathrm{K}$ was determined using flame photometer described by Bhargava and Raghupati (1993), plant digest (using HNO and $\mathrm{HClO}$ mixture for digestion) were 3 4prepared and analyzed for $\mathrm{Cu}, \mathrm{Fe}, \mathrm{Mn}$ and $\mathrm{Zn}$ using the atomic absorption spectrophotometer described by Lindasy and Norvell (1978).

\section{Fruit sampling and analysis}

A composite fully matured fruit samples were taken from four trees in each orchard of the soil series and packed in a plastic bag with sample label. Fruit samples for mosambi were collected during the month of AugustSeptember, 2015 for studying the physical and chemical characteristics of mosambi fruits.

\section{Results and Discussion}

\section{Phsico-chemical and soil fertility status of mosambi orchards}

Data presented in Table 1 revealed that $\mathrm{pH}$ of soil depths i.e. 0-30 and 30-60 cm varied from 8.32 to 8.82 and 8.08 to 8.48 with mean value 8.54 and 8.25 in Jamsar series and 8.52 to 9.12 and 8.11 to 8.56 with mean value 8.83 and 8.41 in Lunkaransar soil series. The $\mathrm{EC}_{2}$ of $0-30$ and $30-60 \mathrm{~cm}$ soil depths were ranged between 0.17 to 0.85 and 0.06 to 0.74 with mean value 0.46 and 0.35 in Jamsar series and 0.92 to 0.99 and 0.75 to 0.92 with mean value 0.96 and 0.85 in Lunkaransar soil series. The $\mathrm{CaCO}_{3}$ values of soil depths, viz0-30 and 30$60 \mathrm{~cm}$ were ranged between 20.85 to 67.89 and26.49 to 71.35 with mean value 39.64 and 43.50 in Jamsar soil series and 28.92 to 66.45 and 32.09 to 81.89 with mean value 48.31 and 51.04 in Lunkaransar series. Series wise, range and mean values of organic carbon content of different soil layers were recorded 0.33 to 2.15 with the mean value 1.08 in $0-30$ $\mathrm{cm}, 0.20$ to 1.44 with mean value 0.92 in 30 $60 \mathrm{~cm}$ depth in Jamsar series, 0.21 to 0.93 with mean value 0.55 in $0-30 \mathrm{~cm}$ and 0.22 to 0.41 with mean value 0.32 in $30-60 \mathrm{~cm}$ depths in Lunkaransar series of Bikaner district.

The available $\mathrm{N}$ content of soils in $0-30$ and $30-60 \mathrm{~cm}$ depths were ranged between 63.48 to 99.43 and 60.59 to 96.25 with mean value 84.30 and 80.51 in Jamsar series and 57.15 to 96.47 and 52.14 to 92.36 with mean value 78.59 and 74.71 in Lunkaransar soil series of Bikaner district. The available $\mathrm{P}$ content in soil depths of 0-30 and 30-60 cm were ranged between 5.44 to 32.02 and 2.78 to 27.10 with mean value 19.0 and 16.11 in Jamsar series, 5.16 to 30.44 and 4.96 to 29.36 with mean value 18.48 and 15.97 in Lunkaransar series. The available $\mathrm{K}$ content of soils were varied from 118.95 to 336.88 and 108.65 to 322.26 with mean values 210.15 and 194.32 in Jamsar 
series, 86.58 to 319.54 and 82.65 to 316.85 with mean values 178.53 and 173.62 in Lunkaransar series.

The relative high $\mathrm{pH}$ of these orchard soils might be due to dominance of $\mathrm{CO}_{3}^{-2},+\mathrm{HCO}_{3}^{-}$ of $\mathrm{Ca}^{2+}, \mathrm{Mg}^{2+}$ providing $\mathrm{OH}^{-}$ions. The $\mathrm{pH}$ of study area was varied from normal to alkaline. Accumulation of bases especially $\mathrm{Na}^{+}$under low rainfall conditions seen to be the primary reason for alkaline soil reaction. The EC values of surface soils were slightly higher as compared to sub-surface soils. The higher values of EC of surface soils might be due to high evaporation demand of the aridecosystem due to prevailing high temperature and low rainfall and irrigating soils with poor quality underground waters. Increase in the $\mathrm{CaCO}_{3}$ content with increased soil depths indicates that the calcium leached down from surfaces oil to sub-surface soils and accumulated in the form of calcium carbonate as secondary carbonate by the precipitation. Low content of organic carbon in the soils of all the soil series appears to be mainly due to the type of climate of region. It is difficult to build up organic matter in the soils of arid regions on account of high temperatures which causes rapid oxidation of organic matter. The results of investigation are in close agreement with the findings Fida et al., (2011), Singh and Kumar (2012), Bhatnagar and Singh (2014), Rathod et al., (2016) and Yadav and Gupta (2018). The cause of low available nitrogen content in all these soils had been due to the absence of natural vegetation, low organic carbon, low precipitation \& high temperature which aggravates decomposition of organic matter by enhancing oxidation and aeration.

The soils of the study area were found to be low to medium in available phosphorus content. A satisfactory potassium status of the studied area might be due to potash bearing minerals (muscovite, biotite and feldspar) which on weathering slowly release potash.
The results of present study are in confirmation with those reported by Singh and Kumar (2012), Srivastava and Patil (2016) and Bagdiet al., (2017).

\section{Soil micronutrient status of mosambi orchards}

Data presented in Table 2 revealed that the available Fe content of soils in 0-30 and 30-60 $\mathrm{cm}$ depths were varied from 1.72 to 4.39 and 1.55 to 4.01 with average values 3.04 and 2.77 in Jamsar series, 1.92 to 4.95 and 1.71 to 4.54 with average values 3.27and 2.91 in Lunkaransar series. The available manganese content of 0-30 and 30-60 cm soil layers were varied from 2.36to 5.96 and 2.92 to 5.82 with average values 3.72and 3.55 in Jamsar series and 2.46 to 4.88 and 2.35 to 4.92 with average values 3.46 and 3.36 in Lunkaransar series. The available copper content of soils were ranged between 0.08 to 0.30 and 0.08 to 0.29 with average values 0.18 and 0.16 in Jamsar series and 0.11 to 0.22 and 0.06 to 0.14 with average values 0.15 and 0.11 in Lunkaransar series. The available $\mathrm{Zn}$ content of soils in 030 and $30-60 \mathrm{~cm}$ depths were varied from 0.18 to 0.54 and 0.12 to 0.53 with an average values 0.32 and 0.29 in Jamsar series, 0.11 to 0.60 and 0.09 to 0.59 with an average values 0.3 and 0.27 in Lunkaransar series of Bikaner district.

The soils of study area were found low in available iron content due to calcareous soil. A satisfactory available Mn status was found in studied area. The available copper status of orchard soils were found low to sufficient might be due to high $\mathrm{pH}$, calcareousness, organic carbon status and light texture of soil. Calcareous nature and low organic matter are some of the other properties where low levels of $\mathrm{Zn}$ are anticipated. The results of investigation are in close agreement with the findings Sharma and Choudhary (2007), Somasundaram et al., (2011), Singh and 
Chandra (2012) and Srivastava and Patil (2016) also reported decreasing trend of available iron from surface to subsurface layers of soil.

\section{Nutrient contents status in mosambi leaves}

Astudy of the data in Table 3 showed that the leaf $\mathrm{N}$ content in mosambi leaves were collected during the month of March-April, 2015 ranged from 0.36 to 1.10 with a mean value 0.73 per cent in Jamsar series, 0.32 to 1.29 with a mean value 0.6 per cent in Lunkaransar series. The Pcontent in mosambi leaves varied from 0.14 to 0.36 with mean value 0.23 per cent in Jamsar series, 0.09 to 0.28 with mean value 0.16 per cent in Lunkaransar series. The $\mathrm{K}$ content in leaves showed a range of 0.33 to 0.72 with mean value 0.53 per cent in Jamsar series, 0.36 to 0.66 with mean value 0.50 per cent in Lunkaransar series. The $\mathrm{Fe}$ content in the leaves varied from 129.54 to 282.54 with mea value $203.01 \mathrm{mg} \mathrm{kg}^{-1}$ in Jamsar series, 122.51 to 285.61 with mean value $188.18 \mathrm{mg} \mathrm{kg}$ at Lunkaransar series. The Mn-1 content inmosambi leaves ranged from 18.55 to 31.72 with mean value 25.18 in Jamsar series, 14.22 to 28.99 with mean value 21.11 in Lunkaransar series. The $\mathrm{Cu}$ content in leaves of mosambi orchards were ranged between 7.06 to 15.66 with the mean value 10.72 in Jamsar series, 5.07 to 12.55 with the mean value 9.70 in Lunkaransar series. The $\mathrm{Zn}$ content in leaves of mosambi orchards were ranged from 13.20 to 20.32 with mean value 16.63 in Jamsar series, 10.29 to 19.22 with mean value 14.90 in Lunkaransar series.

The low concentration of nitrogen in leaves of these plants might be due to low nitrogen status of soils, poor organic matter content, high $\mathrm{pH}$ and less application of nitrogen. Besides, soils of the study area are sandy in nature; therefore, leaching of nitrogen was more which might cause reduction in its uptake. The content of $\mathrm{P}$ in mosambi leaves might be due to medium to high $\mathrm{P}$ status of orchard soils and it proper uptake and utilization by plant tissues. The leaves samples which were found low to medium in potassium content; might be due to sufficient availability of potassium in soils of studied area. The results of present investigation are in accordance with Fida et al., (2011), Srivastava and Patil (2016), Kuchanwar et al., (2017) and Kumar et al., (2017) who reported that nitrogen content decreased with plant or leaf age too. The orchards of study area had 100 per cent samples sufficient in Fe content in leaves. It might be due to sufficient quantity of DTPA iron in soil. The evaluation of leaf samples of mosambi collected from all the soil series orchards showed higher range of $\mathrm{Mn}$ content.

It may be due to low mobility as Mn presented a continuous leaf concentration increase over the time. Majority of leaf samples of mosambi orchards in all the soil series orchards showed optimum leaf $\mathrm{Cu}$ content. The low $\mathrm{Zn}$ content in leaves might be due to low status of available $\mathrm{Zn}$ in the soil, poor status of organic matter content. The results of present investigation are in accordance with Rastogi and Chandra (1987), Maia et al., (2007), Fida et al., (2011) and Srivastava and Patil (2016).

\section{Physical and chemical characteristics of mosambi fruit}

Data in Table 4 showed that the fruit yield was ranged from18.11 to 41.11 with average value 29.37 in Jamsar series, 19.41to 32.94 with average value 25.53 in Lunkaransar series.

The fruit volume was ranged from 131.25 to 195.84 with average value 164.61 in Jamsar series and 132.84 to 189.51 with average value 158.60 in Lunkaransar series. 
Table.1 Physico-chemical and soil fertility parameters of mosambi orchards at different soil series of Bikaner district

\begin{tabular}{|c|c|c|c|c|c|c|c|c|}
\hline \multirow{2}{*}{$\begin{array}{c}\text { Soil } \\
\text { Series }\end{array}$} & \multirow{2}{*}{$\begin{array}{c}\text { Depth } \\
\text { (cm) }\end{array}$} & \multirow[t]{2}{*}{$\mathbf{p H}_{2}$} & \multirow{2}{*}{$\begin{array}{c}\mathrm{EC}_{2}(\mathrm{dS} \\
\left.\mathrm{m}^{-1}\right)\end{array}$} & \multirow{2}{*}{$\underset{\left.\mathrm{kg}^{-1}\right)}{\mathrm{CaCO}_{3}(\mathrm{~g}}$} & \multirow{2}{*}{$\begin{array}{c}\text { Organic } \\
\text { carbon } \\
\left(\mathrm{g} \mathrm{kg}^{-1}\right)\end{array}$} & \multicolumn{3}{|c|}{ Available macronutrients $\left(\mathrm{kg} \mathrm{ha}^{-1}\right)$} \\
\hline & & & & & & $\mathbf{N}$ & $\mathbf{P}_{2} \mathbf{O}_{5}$ & $\mathrm{~K}_{2} \mathrm{O}$ \\
\hline \multicolumn{9}{|c|}{ Jamsar series } \\
\hline \multirow[t]{2}{*}{ Range } & $0-30$ & $8.32-8.82$ & $0.17-0.85$ & $20.85-67.89$ & $0.33-2.15$ & $63.48-99.43$ & $5.44-32.02$ & $118.95-336.88$ \\
\hline & $30-60$ & $8.08-8.48$ & $0.06-0.74$ & $26.49-71.35$ & $0.20-1.44$ & $60.59-96.25$ & $2.78-27.10$ & $108.65-322.26$ \\
\hline \multirow[t]{2}{*}{ Mean } & $0-30$ & 8.54 & 0.46 & 39.64 & 1.08 & 84.3 & 19 & 210.15 \\
\hline & $30-60$ & 8.25 & 0.35 & 43.5 & 0.92 & 80.51 & 16.11 & 194.32 \\
\hline \multirow[t]{2}{*}{ C.V. } & $0-30$ & 1.99 & 56.29 & 41.85 & 70.69 & 15.77 & 39.4 & 40.23 \\
\hline & $30-60$ & 2.06 & 71.62 & 37.73 & 42.27 & 16.49 & 41.02 & 43.04 \\
\hline \multicolumn{9}{|c|}{ Lunkaransar series } \\
\hline \multirow[t]{2}{*}{ Range } & $0-30$ & $8.52-9.12$ & 0.92-0.99 & $28.92-66.45$ & $0.21-0.93$ & $57.15-96.47$ & $5.16-30.44$ & $84.58-319.54$ \\
\hline & $30-60$ & $8.11-8.56$ & $0.75-0.92$ & $32.09-81.89$ & $0.22-0.41$ & $52.14-92.36$ & $4.96-29.36$ & $82.65-316.85$ \\
\hline \multirow[t]{2}{*}{ Mean } & $0-30$ & 8.83 & 0.96 & 48.31 & 0.55 & 78.59 & 18.48 & 178.53 \\
\hline & $30-60$ & 8.41 & 0.85 & 51.04 & 0.32 & 74.71 & 15.97 & 173.62 \\
\hline \multirow[t]{2}{*}{ C.V. } & $0-30$ & 2.49 & 2.97 & 28.35 & 55.27 & 15.47 & 39.11 & 43.67 \\
\hline & $30-60$ & 1.76 & 6.72 & 31.12 & 15.31 & 16.355 & 43.15 & 44.69 \\
\hline
\end{tabular}

Table.2 Soil micronutrient status of mosambi orchards

\begin{tabular}{|c|c|c|c|c|c|}
\hline \multirow{2}{*}{$\begin{array}{c}\text { Soil } \\
\text { Series }\end{array}$} & \multirow{2}{*}{$\begin{array}{c}\text { Depth } \\
\text { (cm) }\end{array}$} & \multicolumn{4}{|c|}{ DTPA extractable micronutrients (mg kg soil $\left.{ }^{-1}\right)$} \\
\hline & & Fe & Mn & $\mathrm{Cu}$ & $\mathbf{Z n}$ \\
\hline \multicolumn{6}{|c|}{ Jamsar series } \\
\hline \multirow[t]{2}{*}{ Range } & $0-30$ & $1.72-4.39$ & $2.36-5.96$ & $0.08-0.30$ & $0.18-0.54$ \\
\hline & $30-60$ & $1.55-4.01$ & $2.92-5.82$ & $0.08-0.29$ & $0.12-0.53$ \\
\hline \multirow[t]{2}{*}{ Mean } & $0-30$ & 3.04 & 3.72 & 0.18 & 0.32 \\
\hline & $30-60$ & 2.77 & 3.55 & 0.16 & 0.29 \\
\hline \multirow[t]{2}{*}{ C.V. } & $0-30$ & 30.62 & 32.76 & 41.01 & 34.32 \\
\hline & $30-60$ & 32.44 & 34.01 & 41.03 & 52.89 \\
\hline \multicolumn{6}{|c|}{ Lunkaransar series } \\
\hline \multirow[t]{2}{*}{ Range } & $0-30$ & $1.92-4.95$ & $2.46-4.88$ & $0.11-0.22$ & $0.11-0.60$ \\
\hline & $30-60$ & $1.71-4.54$ & $2.35-4.92$ & $0.06-0.14$ & $0.09-0.59$ \\
\hline \multirow[t]{2}{*}{ Mean } & $0-30$ & 3.27 & 3.46 & 0.15 & 0.3 \\
\hline & $30-60$ & 2.91 & 3.36 & 0.11 & 0.27 \\
\hline \multirow[t]{2}{*}{ C.V. } & $0-30$ & 30.41 & 21.51 & 27.3 & 51.56 \\
\hline & $30-60$ & 32.68 & 23.65 & 23.33 & 57.34 \\
\hline
\end{tabular}


Table.3 Nutrient contents in mosambi leaves at different soil series of Bikaner district

\begin{tabular}{|c|c|c|c|c|c|c|c|}
\hline \multirow{2}{*}{$\begin{array}{c}\text { Soil } \\
\text { Series }\end{array}$} & \multicolumn{3}{|c|}{ Macronutrients (per cent) } & \multicolumn{4}{|c|}{ Micronutrients $\left(\mathrm{mg} \mathrm{kg}^{-1}\right)$} \\
\hline & $\mathbf{N}$ & $\mathbf{P}$ & K & $\mathbf{F e}$ & Mn & $\mathrm{Cu}$ & $\mathbf{Z n}$ \\
\hline \multicolumn{8}{|c|}{ Jamsar series } \\
\hline Range & $\begin{array}{c}0.36- \\
1.10\end{array}$ & $0.14-0.36$ & $0.33-0.72$ & $129.54-282.54$ & $18.55-31.72$ & $7.06-15.66$ & $\begin{array}{l}13.20- \\
20.32\end{array}$ \\
\hline Mean & 0.73 & 0.23 & 0.53 & 203.01 & 25.18 & 10.72 & 16.63 \\
\hline C.V. & 35.9 & 31.59 & 24.18 & 26.9 & 17.29 & 22.96 & 17.51 \\
\hline \multicolumn{8}{|c|}{ Lunkaransar series } \\
\hline Range & $\begin{array}{c}0.32- \\
1.29\end{array}$ & $0.09-0.28$ & $0.36-0.66$ & $122.51-285.61$ & $14.22-28.99$ & $5.07-12.55$ & $\begin{array}{c}10.29- \\
19.22\end{array}$ \\
\hline Mean & 0.6 & 0.16 & 0.5 & 188.18 & 21.11 & 9.7 & 14.9 \\
\hline C.V. & 49.91 & 35.66 & 20.45 & 25.05 & 23.31 & 26.76 & 22.18 \\
\hline
\end{tabular}

Table.4 Physical and chemical characteristics of mosambi fruits at different soil series of Bikaner district

\begin{tabular}{|c|c|c|c|c|c|c|c|}
\hline Soil Series & $\begin{array}{l}\text { Fruit yield } \\
\left(\text { kg plant }^{-1}\right)\end{array}$ & $\begin{array}{l}\text { Fruit volume } \\
\text { (cc) }\end{array}$ & $\begin{array}{l}\text { TSS } \\
\left({ }^{\circ} \mathrm{B}\right)\end{array}$ & $\begin{array}{l}\text { Ascorbic acid } \\
\text { (mg } 100 \mathrm{~g}^{-1} \\
\text { pulp) }\end{array}$ & $\begin{array}{c}\text { Total } \\
\text { acidity } \\
(\%)\end{array}$ & $\begin{array}{c}\text { Total } \\
\text { sugar } \\
(\%)\end{array}$ & $\begin{array}{c}\text { Reducing } \\
\text { sugar } \\
(\%)\end{array}$ \\
\hline \multicolumn{8}{|c|}{ Jamsar series } \\
\hline Range & $18.11-41.11$ & $131.25-195.84$ & $7.73-10.18$ & $42.47-52.97$ & $0.61-0.89$ & $6.53-9.04$ & $2.13-3.32$ \\
\hline Mean & 29.37 & 164.61 & 8.7 & 46.53 & 0.76 & 7.49 & 2.59 \\
\hline C.V. & 20 & 9.05 & 9.72 & 7.18 & 12 & 10.28 & 14.85 \\
\hline \multicolumn{8}{|c|}{ Lunkaransar series } \\
\hline Range & 19.41-32.94 & 132.84-189.51 & $7.53-9.86$ & 41.01-50.94 & $0.29-0.83$ & $6.38-8.89$ & $1.93-3.00$ \\
\hline Mean & 25.53 & 158.6 & 8.57 & 44.4 & 0.63 & 7.26 & 2.46 \\
\hline C.V. & 15.85 & 10.53 & 9.06 & 7.4 & 28.52 & 10.64 & 12.91 \\
\hline
\end{tabular}

Table.5 Nutrient contents in mosambi fruit juice of different soil series of Bikaner District

\begin{tabular}{|c|c|c|c|c|c|c|c|}
\hline \multirow{2}{*}{$\begin{array}{c}\text { Soil } \\
\text { Series }\end{array}$} & \multicolumn{7}{|c|}{ Nutrient contents $\left(\mathrm{mg} \mathrm{L}^{-1}\right)$} \\
\hline & $\mathbf{N}$ & $\mathbf{P}$ & $\mathbf{K}$ & Fe & Mn & $\mathbf{C u}$ & Zn \\
\hline \multicolumn{8}{|c|}{ Jamsar series } \\
\hline Range & $792.61-1110.25$ & $69.60-130.25$ & $968.92-1268.62$ & $0.22-1.48$ & $0.10-0.36$ & $0.08-0.33$ & $0.08-0.52$ \\
\hline Mean & 993.35 & 95.35 & 1124.66 & 0.68 & 0.21 & 0.19 & 0.28 \\
\hline C.V. & 10.81 & 12.8 & 8.93 & 31.35 & 26.48 & 30.59 & 52.54 \\
\hline \multicolumn{8}{|c|}{ Lunkaransar series } \\
\hline Range & $759.62-1140.58$ & $50.24-102.54$ & $909.65-1282.64$ & $0.23-1.11$ & $0.09-0.33$ & $0.08-0.39$ & $0.11-0.52$ \\
\hline Mean & 887.55 & 81.1 & 1086.78 & 0.46 & 0.18 & 0.16 & 0.26 \\
\hline C.V. & 12.02 & 14.08 & 12.67 & 21.94 & 23.2 & 23.72 & 27.38 \\
\hline
\end{tabular}


Table.6 Correlation coefficients between leaf nutrients concentration and fruit quality and yield of mosambi

\begin{tabular}{|c|c|c|c|c|c|c|c|}
\hline \multirow{2}{*}{$\begin{array}{c}\text { Leaf } \\
\text { nutrients }\end{array}$} & \multicolumn{7}{|c|}{ Fruit yield and quality parameters } \\
\hline & $\begin{array}{l}\text { TSS } \\
\left({ }^{\circ} \mathbf{B}\right)\end{array}$ & $\begin{array}{l}\text { Total } \\
\text { acidity } \\
(\%)\end{array}$ & $\begin{array}{c}\text { Reducing } \\
\text { sugar } \\
(\%)\end{array}$ & $\begin{array}{c}\text { Total } \\
\text { sugar } \\
(\%)\end{array}$ & $\begin{array}{c}\text { Ascorbic acid } \\
\left(\mathrm{mg} / 100^{-1} \mathrm{~g}\right. \\
\text { pulp) }\end{array}$ & $\begin{array}{c}\text { Fruit } \\
\text { volume } \\
\text { (cc) }\end{array}$ & $\begin{array}{l}\text { Fruit yield } \\
\left(\text { kg plant }^{-1}\right)\end{array}$ \\
\hline \multicolumn{8}{|c|}{ Jamsar series } \\
\hline $\mathbf{N}(\%)$ & -0.251 & 0.385 & $0.571^{*}$ & 0.289 & $0.587 *$ & 0.441 & $0.744 * *$ \\
\hline $\mathbf{P}(\%)$ & 0.502 & 0.419 & -0.464 & 0.233 & 0.397 & -0.21 & $0.617 *$ \\
\hline K (\%) & $\begin{array}{c}- \\
0.808^{*} \\
*\end{array}$ & 0.344 & -0.471 & 0.196 & 0.218 & -0.325 & 0.074 \\
\hline $\mathrm{Fe}(\mathrm{ppm})$ & $0.596^{*}$ & 0.126 & 0.393 & $0.502 *$ & $0.673^{*}$ & $0.816^{* *}$ & 0.135 \\
\hline Mn (ppm) & -0.037 & 0.233 & $0.573^{*}$ & -0.198 & 0.16 & $0.657^{*}$ & 0.367 \\
\hline $\mathrm{Cu}$ (ppm) & 0.354 & -0.195 & 0.546 & 0.194 & 0.235 & $0.707 *$ & $0.778^{* *}$ \\
\hline Zn (ppm) & $0.520^{*}$ & 0.247 & 0.443 & 0.327 & 0.376 & $0.702 *$ & $0.846^{* *}$ \\
\hline \multicolumn{8}{|c|}{ Lunkaransar series } \\
\hline $\mathbf{N}(\%)$ & -0.105 & 0.299 & 0.456 & 0.137 & 0.375 & 0.279 & $0.607 *$ \\
\hline $\mathbf{P}(\%)$ & 0.127 & 0.231 & -0.226 & 0.348 & 0.511 & -0.243 & 0.032 \\
\hline K (\%) & $\begin{array}{c}- \\
0.820^{*} \\
*\end{array}$ & 0.283 & -0.39 & 0.03 & 0.23 & -0.301 & 0.157 \\
\hline $\mathrm{Fe}(\mathbf{p p m})$ & 0.496 & 0.111 & $0.816^{* *}$ & 0.444 & $0.657^{*}$ & $0.723^{*}$ & $0.727 *$ \\
\hline Mn (ppm) & 0.036 & 0.131 & 0.491 & 0.251 & 0.126 & 0.467 & 0.469 \\
\hline $\mathrm{Cu}$ (ppm) & 0.185 & -0.215 & 0.542 & 0.178 & 0.286 & 0.402 & 0.407 \\
\hline $\mathrm{Zn}$ (ppm) & 0.164 & -0.223 & $0.551^{*}$ & 0.188 & 0.299 & 0.408 & $0.834^{* *}$ \\
\hline
\end{tabular}

The total soluble solids (TSS) were ranged from 7.73 to 10.18 with average value 8.70 in Jamsar series, 7.53 to 9.86 with average value 8.57 in Lunkaransar series. The ascorbic acid content of mosambi fruits were ranged from 42.47 to 52.97 with average value 46.53 in Jamsar series, 41.01 to 50.94 with average value 44.4 in Lunkaransar series. The total acidity of mosambi fruits were ranged from 0.61 to 0.89 with average value 0.76 in Jamsar series, 0.29 to 0.83 with average value 0.63 in Lunkaransar series. The total sugars were ranged from 6.53 to 9.04 with average value 7.49 in Jamsar series, 6.38 to 8.89 with average value 7.26 in Lunkaransar series. The reducing sugars were ranged from 2.13 to 3.32 with mean value 2.59 in Jamsar series, 1.93 to 3.00 with mean value 2.46 in Lunkaransar series of Bikaner district.

The physical characters of fruits i.e. fruit volume and fruit yields were found relatively higher due to better nutrient management, water availability and quality along with appropriate management might have resulted in better fruit volume and yield similar findings reported by Nasreen et al., (2013), Desai et al., (2014) and Jakhar et al., (2016).

The chemical characteristics of fruits like total soluble solids, total acidity, reducing sugar and total sugar content series wise differences 
due to variation in soil nutrient status of the orchards. These results get support from the findings of Kaul et al., (2014) who studied the response of soil nutrient status on leaf nutrient content and fruit yield of mosambi at different locations of seven mosambi orchards at Sriganganagar district of Rajasthan, India, during 2005-06.

The results showed that average fruit weight, T.S.S., acidity, ascorbic acid, juice content and fruit yield varied between 108.96 to $151.39 \mathrm{~g}$, 10.40 to $11.60{ }^{\circ}$ Brix, 0.98 to $1.02 \%, 32.93$ to $36.02 \mathrm{mg} 100 \mathrm{~g} \mathrm{pulp}^{-1}, 51.80$ to $55.70 \mathrm{ml}$ and 47.53 to $71.33 \mathrm{~kg}$ plant $^{-1}$, respectively. Similar results were also reported by Bhatnagar and Singh (2014), Bhatnagar et al., (2015) and Pawar et al., (2017).

Nutrient content status of mosambi fruit juice

Data presented in Table 5 indicated that the $\mathrm{N}$ content in mosambi fruit juice at ranged from 792.61 to 1110.25 with mean value 993.35 in Jamsar series, 759.62 to 1140.58 with mean value 887.55 in Lunkaransar series. The $\mathrm{P}$ content of mosambi fruits ranged from 69.60 to 130.25 with mean value 95.35 at Jamsar series, 50.24 to 102.54 with mean value 81.10 in Lunkaransar series.

The $\mathrm{K}$ content in mosambi fruit juice was ranged from 968.92to 1268.62 with mean value 1124.66 at harvest in Jamsar series, 909.65 to 1282.64 with mean value 1086.78 in Lunkaransar series. The $\mathrm{Fe}$ content in the mosambi fruit juice varied from 0.22 to 1.48 with mean value $0.68 \mathrm{ppm}$ at Jamsar series, 0.23 to 1.11 with mean value 0.46 in Lunkaransar series.

The mosambi juice $\mathrm{Mn}$ content varied from 0.10 to 0.36 with mean value 0.21 at Jamsar series, 0.09 to 0.33 with mean value 0.18 in Lunkaransar series. The variation in $\mathrm{Cu}$ content of mosambi fruit juice was observed from 0.08 to 0.33 and 0.08 to 0.39 with mean value 0.19 and $0.16 \mathrm{ppm}$ at Jamsar and Lunkaransar series. The mosambi fruit juice $\mathrm{Zn}$ content varied from 0.08 to 0.52 and 0.11 to 0.52 with mean values of 0.28 and 0.26 ppm at Jamsar and Lunkaransar series of Bikaner series. Singh et al., (2015) reported the concentrations of macronutrients $(\mathrm{N}, \mathrm{P}, \mathrm{K}$, $\mathrm{Ca}$ and $\mathrm{Mg}$ ) and micronutrients ( $\mathrm{Fe}, \mathrm{Zn}, \mathrm{Mn}$ and $\mathrm{Cu}$ ) in the fruit peel and pulp from grapefruit cv. Star Ruby fruits at monthly intervals during fruit development. Similarly results were also reported by Li-ying et al., (2008).

\section{Correlation coefficients between leaf nutrients and fruit quality of mosambi}

The estimates of correlation between different variables measured from two different soil series under irrigated area of arid Rajasthan is given in Table 6.

Jamsar series the leaf $\mathrm{N}$ content had a significant correlation with reducing sugar $(\mathrm{r}=$ $0.571 *)$, ascorbic acid $(\mathrm{r}=0.587 *)$ and fruit yield $\left(\mathrm{r}=0.744^{* *}\right)$; leaf $\mathrm{P}$ content with fruit yield $(\mathrm{r}=0.617 *)$; leaf $\mathrm{K}$ content was negatively correlated with TSS $\left(\mathrm{r}=-0.808^{* *}\right)$; leaf Fe content with TSS $\left(r=0.596^{*}\right)$, total sugar $\left(r=0.502^{*}\right)$, ascorbic acid $\left(r=0.673^{*}\right)$ and fruit volume $\left(\mathrm{r}=0.816^{* *}\right)$; leaf $\mathrm{Mn}$ content was positively correlated with reducing sugar $(\mathrm{r}=0.573 *)$ and fruit volume $(\mathrm{r}$ $=0.657 *)$; leaf $\mathrm{Cu}$ content with fruit volume $(\mathrm{r}$ $=0.707 *)$ and fruit yield $\left(\mathrm{r}=0.778^{* *}\right)$; while leaf $\mathrm{Zn}$ content with TSS $\left(\mathrm{r}=0.520^{*}\right)$, fruit volume $(\mathrm{r}=0.702 *)$ and fruit yield $(\mathrm{r}=$ $\left.0.846^{* *}\right)$.

Lunkaransar series the leaf $\mathrm{N}$ content significantly correlated with fruit yield $(\mathrm{r}=$ $\left.0.607^{*}\right)$; leaf $\mathrm{K}$ content negatively correlated with TSS $(\mathrm{r}=-0.820 * *)$; leaf $\mathrm{Fe}$ content positively correlated with reducing sugar ( $\mathrm{r}$ 
$\left.=0.816^{* *}\right)$, ascorbic acid $\left(\mathrm{r}=0.657^{*}\right)$, fruit volume $\left(\mathrm{r}=0.723^{*}\right)$ and fruit yield $(\mathrm{r}=$ $\left.0.727^{*}\right)$; leaf $\mathrm{Zn}$ content significantly and positively correlated with reducing sugar $(\mathrm{r}$ $\left.=0.551^{*}\right)$ and fruit yield $\left(\mathrm{r}=0.834^{* *}\right)$.

Perusal of the data revealed positive and significant correlation coefficients between leaf $\mathrm{N}, \mathrm{P}, \mathrm{K} \mathrm{Cu}$ and $\mathrm{Zn}$ with fruit volume and fruit yield. Since all the characteristics depend upon vegetative growth of the plant which are influenced by nitrogen. These results are in accordance with the findings of Kumar et al., (1998). Significant positive correlation was observed between mosambi leaf macronutrients content and fruit yield while leaf $\mathrm{Zn}$ content with both yield and quality of fruits (Marathe et al., 2012). Positive and significant relationship of leaf $\mathrm{N}$ with acidity is in agreement with that of Dalal et al., (2011).

\section{Suggested nutrient management recommendations for mosambi orchards}

On the basis of soil series, potentialities and limitations, following nutrient management recommendations are being suggested for obtaining optimum mosambi fruit production from the orchards at Jamsar and Lunkaransar soil series of Bikaner districts in irrigated area of arid Rajasthan. The soils of mosambi orchards were found low in organic carbon and available $\mathrm{N}$, low to medium in available $\mathrm{P}$ and medium to high in available $\mathrm{K}$. Therefore, well decomposed $100 \mathrm{~kg}$ F.Y.M. along with $2.00 \mathrm{~kg}$ urea and $2.20 \mathrm{~kg}$ single super phosphate per plant must be applied before planting. Full dose of single super phosphate and potash and half dose of urea should be applied during the month of February and the remaining dose of urea applied in the month of August. If we use vermicompost then apply $100 \mathrm{~kg}$ well decomposed vermicompost along with $1 \mathrm{~kg}$ urea. The SSP dose will remain same as above for mosambi plants.
Micronutrient status in mosambi orchards at Jamsar and Lunkaransar soil series were found low in available $\mathrm{Fe}$, low to sufficient in available $\mathrm{Cu}$, high in available $\mathrm{Mn}$ and majority of soil samples were found low in available $\mathrm{Zn}$. The foliar application of $\mathrm{FeSO}_{4}$, $\mathrm{CuSO}_{4}$ and $\mathrm{ZnSO}_{4} @$ of $150 \mathrm{~g}$ each for $\mathrm{Fe}, \mathrm{Cu}$ and $\mathrm{Zn}$ content should be applied per plant per annum.

The High $\mathrm{pH}_{2}$ values, $\mathrm{CaCO}_{3}$ content and $\mathrm{EC}_{2}$ in soil samples were observed at mosambi orchards in Lunkaransar series of Bikaner district. The low in organic carbon, available $\mathrm{N}$ and low to medium in available $\mathrm{P}_{2} \mathrm{O}_{5}$ and medium to high in available $\mathrm{K}_{2} \mathrm{O}$, low in available $\mathrm{Fe}$, high in available $\mathrm{Mn}$, low to medium in available $\mathrm{Cu}$ and low in available $\mathrm{Zn}$ contents. Leaf samples of mosambi were found low in $\mathrm{N}$, optimum in $\mathrm{P}$, low in $\mathrm{K}$, low to high in $\mathrm{Mn}$, optimum in $\mathrm{Cu}$ and low in $\mathrm{Zn}$ content, whereas, Fe content was found low to high in mosambi of the studied area. The fruit yield, quality and nutrient status of mosmabi fruits were found superior in Jamsar as compared to Lunkaransar soil series. Fruit juice samples of mosambi were found low to optimum in $\mathrm{N}, \mathrm{P}$ and $\mathrm{K}$, low to high in $\mathrm{Fe}$ and $\mathrm{Mn}$ contents. The $\mathrm{Cu}$ content in mosambi fruit juice was found low to high and $\mathrm{Zn}$ in low to optimum range of the studied area.

\section{References}

Bagdi D L, Sharma MK, Sharma S L, Bagri GK and Shekhawat P S. 2017. Nutritional survey of ber orchards in Jodhpur and Pali district of Rajasthan.

Journal of Pharmacognosy and Phytochemistry. 6(6): 1936-1938.

Bhargava B S and Raghupati H B. 1993. (in) Methods of Analysis of Soils, Plants, Waters and Fertilizers. pp. 49-82. H.L.S. Tandon (Ed.) Fertiliser Development and Consultation Organization, New Delhi. pp. 41. 
Bhatnagar P, Sharma MK and Singh J. 2015. Analysis of fruit quality of Kinnow mandarin hybrid in arid irrigated areas of Rajasthan. Hort. Flora Research. Spectrum. 4(1): 52-55.

Dalal R P S, Navjot Thakur A and Brar J S. 2011. Effect of foliar application of nutrients on leaf mineral composition and yield of ber (Ziziphus mauritiana Lamk.) under arid conditions. Annals of Arid Zone. 50(1): 53-56.

Desai S M, Hasan A, Sonawane G B, Rajurkar and Singh D. 2014.Effect of different levels of drip irrigation and potassium fertilizer on fruit yield and quality of Kinnow (Citrus reticulate Blanco). International Agricultural Engineering Journal. 23 (2): 50-56.

Fida M, Khan S, Razaaq A, Nawez I and Haq I U. 2011.Fertility status of guava orchards in Kohat district of Pakistan. Journal of Soil Science and Environmental Management. 3(9): 260-268.

Hutchinson H B and McLennan K J. 1914. Agricultural Sciences. 6: 323 -327.

Jackson M L. 1973. Soil Chemical Analysis. Prentice Hall of India Pvt. Ltd., New Delhi. pp. 498.

Jakhar R K, Singh A K, Kaswan P K and Kumawat N. 2016. Effect of drip irrigation and plastic mulch on performance of kinnow and sweet orange grown in arid regions. The Bioscan. 11(3): 1663- 1665.

Kaul M K, Bhatnagar P and Singh J. 2014. Response of soil nutrient status on leaf nutrient content and fruit yield of 'kinnow' mandarin under drip irrigation system. Acta. Horticulture. 1015: 339348.

Kuchanwar O D, Bhujade N H, Chopde N K and Patil B S. 2017. Effect of fertigation on leaf nutrient content and fruit quality of high density plantation of Nagpur mandarin. Journal of
Pharmacognosy and Phytochemistry. 6(6): 1711-1713.

Kumar R, Kumar D, Singh B and Sharma R C. 1998. Nitrogen, phosphorus and potassium requirements of kinnow in low fertility soils of Punjab. Indian Journal of Horticulture. 55(3): 232235.

Kumar N C J, Rajangam J and Balakrishnan K. 2017. Influence of foliar fertilization of micronutrients on leaf macro nutrient status of mandarin orange (Citrus reticulate Blanco.) in lower PulneyHills, International Journal of Pure and Applied Bioscience. 5(2): 1121-1125.

LindsayWL and Norvell WA. 1978. Development of DTPA soil test for zinc, iron, manganese and copper. Soil Science Society of American Journal. 42: 421-428.

Li-ying N, Ji-hong WU, Xiao-jun L, Fang C, Zheng-fu W, Guang-hua $\mathrm{Z}$ and Xiaosong H U. 2008. Physicochemical characteristics of orange juice samples from seven cultivars. Agricultural Sciences in China. 7(1): 41-47.

Maia J L T, Bassoi L H, Silva D J, Lima M A C D, Assis J S D and Morais P L D. 2007. Assessment on nutrient levels in the aerial biomass of irrigated guava in Sao Francisco Valley, Brazil. Revista Brasileira de Fruticultura. 29(3).

Marathe R A, Bharambe P R, Sharma R and Sharma U C. 2012. Leaf nutrient composition, its correlation with yield and quality of sweet orange and soil microbial population as influenced by INM in Vertisol of central India. Indian Jour. Of Hortic. 69(3): 317321.

Metson A J. 1956. Methods of chemical analysis for soil survey samples. Soil Bureau Bulletin - New Zealand, Department of Scientific and Industrial Research. pp. 12. 
NasreenS, Ahmed R, Ullah MA and Hoque MA. 2013. Effect of N, P, K and Mg application on yield and fruit quality of mandarin (Citrus reticulata). Bangladesh Journal of Agricultural Research. 38(3): 425-433.

NHB.2016-17. National Horticulture Board, Horticulture Information Service2016-2017.

Olsen S R, Cole CW, Watanabe F S and Dean LA. 1956. Estimation of available phosphorus in soil by extraction with HNO3. diagnosis and improvement of saline and alkali soils. United State Department of Agriculture, Handbook No.60.

Pawar P S, Khade K R and Bhite B R. 2017.Effect of micronutrients on growth, yield and quality of sweet orange (Citrus sinensis Osbeck) cv.Mosambi.Bioinfolet.14 (2) :202-204

Piper C S. 1950.Soil and Plant Analysis. InterService Publishers, Inc., NewYork.pp. 368.

Rastogi S K and Chandra A. 1987.Nutrient status of newly planted orchards. Fertilizer News.32:47-48.

Rathod S M, Sable P B and Jagtap P S. 2016.Studies on soil nutrient status in relation to yield attributes of sweet orange (Citrus sinensis L.) cv. Nucellar. International Journal of Agriculture Sciences.8 (54) :28772880.

Richards L A. 1954.Diagnosis and improvement of saline and alkaline soils.USDA Handbook No. 60, Oxford and IBH Publication Company, New Delhi.

Sharma J C and Chaudhary S K. 2007.Vertical distribution of micronutrient cations in relation to soil characteristics in lower Shiwaliks of Solan in North-West Himalaya. Journal of Indian Society of Soil Science.55:40-44.

Shyampura R L, Singh S K, Singh R S, Jain B
L and Gajbhiye K S. 2002. Soil Series of Rajasthan, National Bureau of Soil Survey and Land Use Planning, Publication No. 95, Nagpur, pp. 364.

Singh B and Chandra A. 2012.Nutritional survey of aonla orchards in Sikar Dist. of Rajasthan. Lambert Academic Publishing. pp. 168.

Singh H P, Chadha K L and Bhargava B S. 1989. Leaf sampling techniques in acid lime (Citrus auratifolia Swing.) for nutritional diagnosis. Indian Journal of Horticulture. 47(2): 133-139.

Singh J and Kumar R. 2012. Influence of soil nutrient status on yield and qualitative attributes of pomegranate (Punica granatumL.). and ber (Zizyphusm auritiana lamk.). Hort. Flora Research Spectrum. 1(1): 5-12.

Singh S, Gill P P S, Aulakh P S and Singh S. 2015. Changes of minerals in fruit peel and pulp of grapefruit (Citrus paradise Macf.) cv. Star Ruby during fruit development. Research on Crops. 16(4): 669-674.

Snell F D and Snell C T. 1949. ColorimetricMethodsofAnalysis. $\quad 3^{\text {rd }}$ Ed., Vol. 2D. Van Nostrand Co. Inc., Priceton, New York.

Somasundaram J, Meena H R, Singh R K, Prasad S N and Parandiyal A K. 2011.Diagnosis of micronutrient imbalance in lime crop in semi-arid region of Rajasthan India. Communications in Soil Science \& Plant Analysis. 42(7): 858-869.

Srivastava A K and Patil P. 2016. Nutrient Indexing in Kinnow Mandarin (Citrus deliciosia Lour. $\times$ Citrus nobilis Tanaka) grown in Indogangetic Plains. Communications in Soil Science and Plant Analysis. 47(18): 2115-2125.

Subbiah B V and Asija G L. 1956. A rapid procedure for the estimation of the available nitrogen in soil. Current Science. 25: 259-260. 
Yadav B K and Gupta N. 2018. Enzyme activities and nutrient status in soil under ber (Ziziphus mauritiana L.) plants in semi-arid region of Punjab,
India. International Journal of Current Microbiology and Applied Sciences. 7(1): 479-490.

\section{How to cite this article:}

Dinesh Kumar, B. L. Kumawat, B. D. Sharma and Ramandeep Kaur. 2019. Nutritional Survey of Mosambi Orchards at Jamsar and Lunkaransar Soil Series of Bikaner District of Arid Rajasthan. Int.J.Curr.Microbiol.App.Sci. 8(12): 406-418. doi: https://doi.org/10.20546/ijcmas.2019.812.054 